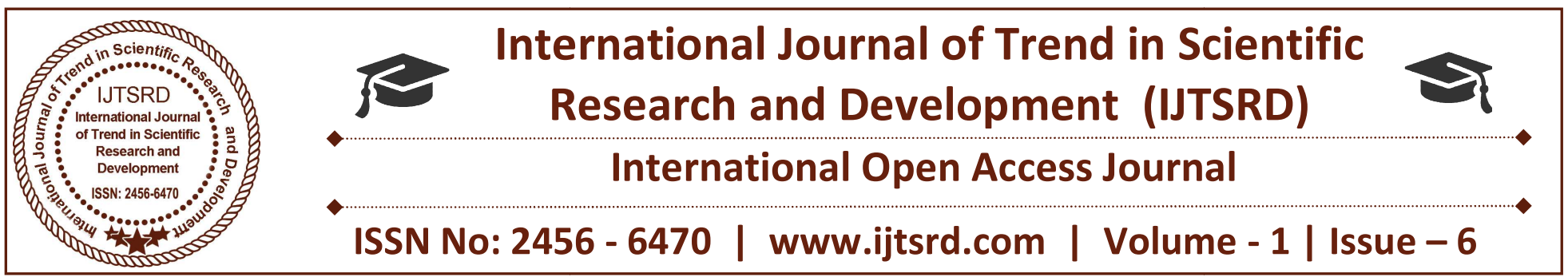

\title{
The Relationship of Emotional Intelligence with Anxiety among Students
}

\section{Sajad Ahmad Bhat}

PhD Research Scholar, Department of Psychology Aligarh Muslim University, Aligarh, India

\author{
Tabassum Farooq \\ PhD Research Scholar, Department of Psychology \\ Aligarh Muslim University, Aligarh, India
}

\section{ABSTRACT}

Anxiety is not a new term in the educational environment in modern times. From exam anxiety to adjustment problem at the school or university, anxiety has adverse effects on the performance and level of mental health of students. Emotional intelligence provides us the ability to deal effectively with the stress and anxiety at School. At school, there were students of different social, cultural and economic strata so the school environment has a different impact on their level of affiliation and interaction. The present study aims at to uncover the relationship between these two constructs at school environment. Emotional intelligence construct is measured by Schutte Self-Report Emotional Intelligence Test (SSEIT 1998). The construct of anxiety was measured by Beck's Anxiety Inventory (1988). Sixty (60) students from Aligarh Muslim University constitute the sample of this study. The collected data was analyzed by Correlation and t-test through SPSS. The results revealed that there is a Negative correlation between the emotional intelligence and anxiety $(\mathrm{r}=-0.34, \mathrm{p}<.001)$. The results also suggested that there is no significant difference between the emotional intelligence in terms of gender $(t=0.790, p=.433)$. But there is a significant difference between in level of anxiety across gender with males scoring slightly higher than females $(t=2.172, p=.035)$. Students high on the dimension of emotional intelligence showed more maturity towards the stressful situations than subjects low on emotional intelligence thus experiencing less anxiety.

Keywords: Emotional Intelligence, Anxiety, Examination Anxiety

\section{INTRODUCTION}

\section{Anxiety}

Anxiety as a term has long been used in social, environmental and institutional context. Anxiety is the apprehension about the things and events that had yet to come. Anxiety is a normal emotion and everyone is experiencing it from time to time. Anxiety can also be defined as anticipation and fear of future. In the modern busy time everyone is experiencing anxiety to some extent on daily basis but the kind of anxiety that becomes overwhelming on the resources of an individual or when the individual becomes unable to cope with this anxiety, at that very time it becomes problematic and can hamper the overall growth of an individual and impairs his daily functioning.

Anxiety is also seen as a major symptom in various psychological disorders, especially in Obsessivecompulsive disorder and PTSD. Anxiety also comorbid with Sleeplessness,, inability to make decisions, nervousness, heart palpitations, low selfesteem, low academic performance. Fear of exams, social gathering and much more can become the causes of anxiety and sometimes results in Social Phobia. The expectations from parents and peers are also a reason believed to be the cause of anxiety. The standards set forth by parents when seems unable to achieve results in anxiety.

\section{Emotional Intelligence}

Emotions are very important part of our lives and we are following them without realizing it. Emotions define a person and sometimes shape the person's world around him. Etymologically emotions are state 
of feeling involving cognitions, biological changes and expression or behavior about any external event or thing. Emotions shapes our thought process thus influences our decision-making ability. According to Birch(1995) "feelings are that what matters the most in life"

Emotional Intelligence is the ability of an individual to be aware of his emotions and feeling and that of others and use this knowledge in relationships, at school, job so that they foster the success instead of roadblocks According to Travis Bradberry and Jean Graves "Emotional intelligence is your ability to recognise and understand your emotions and your skill at using this awareness to manage yourself and your relationship with others"

The concept of emotional intelligence has its roots in Darwin theory who posited that Emotional expression was important for survival. The term Emotional Intelligent was coined by Salovey and Mayer in 1990 and the concept was popularised in 1995 by Goleman in his popular book "Emotional intelligence why it matters more than IQ".

Those who are high on the emotional intelligence dimension are more likely to experience less negative impacts by anxiety driven events. They have very good understanding of physical, mental and social consequences of negative emotions on the well-being and overall development their relationships of life.

Emotional intelligent people are more likely be successful in the workplace because they can understand the emotions of people and also understands why these people behave the way they behave. They are also likely well adjusted within the social contexts and frameworks whether it's a school, any social group. In such situations, emotionally intelligent people manage their own emotions and understand the emotion of others as well.

On the one side of the quantum people high on the dimension of emotional intelligence experience the healthy balance of feelings like freedom, self-control, friendship, autonomy, appreciation, and contentment. On the other side people low on this dimension don't enjoy such kind of feelings and find them engulfed with the feelings of loneliness, guilt, fear, frustration.

\section{OBJECTIVES:}

I. To access the emotional intelligence among university students.

II. To access the Level of Anxiety among University Students.

III. To access the relationship between the emotional intelligence and anxiety among the university students.

\section{Material and Method}

The study employed descriptive research design to carry out the investigation. In this, the investigator tries to find out the relationship between anxiety and emotional intelligence of students at Aligarh Muslim University. The aim was to find out the relationship between these constructs at school/university environment.

\section{Participants}

The simple random sampling method was employed by the researcher to collect the data for the study. Fifty Nine (59) students studying at Aligarh Muslim University were approached for this study. The data was collected in a way to comprises both Male and female students. The total number of males and females are 30 and 29 respectively.

\section{Tools Used}

Beck's Anxiety Inventory (BAI) developed by Beck in 1988 was used to measure the construct of Anxiety. SAI has good psychometric properties.

Reliability Properties are: Internal consistency for the BAI $=($ Cronbach's $\alpha=0.92)$, Test-retest reliability (1 week) for the BAI = 0.75 (Beck, Epstein,Brown, \& Steer, 1988).

Validity properties of BAI are: The BAI was moderately correlated with the revised Hamilton Anxiety Rating Scale (.51), and mildly correlated with the Hamilton Depression Rating Scale (.25) (Beck et al., 1988)

Emotional intelligence construct was measured by Schutte Self-Report Emotional Intelligence Test (SSEIT 1998)

\section{Analysis of Data}

The data collected were classified, tabulated and subjected to statistical analysis by using SPSS. Mean, SD and coefficient of correlation were calculated.

\section{Analysis and Findings :}

After the analysis of data, following results were obtained. 


\section{Descriptive Table 1.1}

\begin{tabular}{|c|c|c|c|c|c|c|c|c|c|c|}
\hline \multirow[t]{3}{*}{ Variables } & & \multicolumn{2}{|c|}{$\begin{array}{l}\text { Leven's test } \\
\text { for equality } \\
\text { of variances }\end{array}$} & \multicolumn{7}{|c|}{ T-Test for equality of means } \\
\hline & & \multirow[t]{2}{*}{$\mathrm{F}$} & \multirow[t]{2}{*}{ Sig. } & \multirow[t]{2}{*}{$\mathrm{T}$} & \multirow[t]{2}{*}{$\mathrm{df}$} & \multirow[t]{2}{*}{$\begin{array}{l}\text { Sig(two- } \\
\text { tailed) }\end{array}$} & \multirow[t]{2}{*}{$\begin{array}{l}\text { Mean } \\
\text { diff }\end{array}$} & \multirow[t]{2}{*}{$\begin{array}{l}\text { Std } \\
\text { error } \\
\text { diff }\end{array}$} & \multicolumn{2}{|c|}{$\begin{array}{l}95 \% \\
\text { Confidence } \\
\text { Interval }\end{array}$} \\
\hline & & & & & & & & & Lower & Upper \\
\hline $\begin{array}{l}\text { Emotional } \\
\text { Intelligen } \\
\text { ce }\end{array}$ & $\begin{array}{l}\text { Equal } \\
\text { Variances } \\
\text { not } \\
\text { assumed }\end{array}$ & 0.08 & .928 & .790 & 57 & .433 & 3.02 & 3.83 & -4.64 & 10.70 \\
\hline Anxiety & $\begin{array}{l}\text { Equal } \\
\text { Variances } \\
\text { not } \\
\text { assumed }\end{array}$ & 7.50 & .008 & 2.15 & 57 & .035 & 1.64 & .762 & .115 & 3.16 \\
\hline
\end{tabular}

In the above table mean and standard deviation of the said variable is given.

\section{Correlation Table 1.2}

Pearson Correlation

EI

$\mathbf{A N}$
Sig.(2-tailed)

$\mathbf{N}$

Pearson Correlation

Sig. (2-tailed)

$\mathbf{N}$

\section{El}

1

59

$-.034$

.789

59
AN

$-.034$

.798

59

1

59
The above table shows the Pearson correlation between emotional intelligence and Anxiety among students. The correlation coefficient reflects there is a negative correlation between the emotional intelligence and anxiety students. The findings suggest that those students who manage their emotion effectively are less vulnerable to anxiety situations.

\section{Recommendations}

The implications and recommendations of the present paper are in tune with the findings that suggests that improving the levels of emotional intelligence can lower the chances of roll over by anxiety and other adverse events. People who manage their emotions well at school, workplace get better adjusted to these kinds of environments and those who are low on dimensions of emotional intelligence are more likely get over by negative emotions taht ultimately lead them into stress and anxiety.

\section{References}

1) Aminuddin, H., Tajularipin, S. \& Rohaizan, I. (2009). Philosophy underlying emotional intelligence in relation to the level of curiosity and academic achievement of rural area students. Journal of Social Sciences, 5(2), 95-103.

2) A., Tella, A. \& Tella, A. (2006). The relationship among emotional intelligence, parental 
involvement and academic achievement of secondary school students in Ibadan, Nigeria. Essays in Education, 18.Retrieved May 1, 2016, from

http://www.usca.edu/essays/vol1 82006/tella1.pdf

3) Ebrahimi, R.M., \& Khoshima, H. (2014). On the Association(s) between Test Anxiety and Emotional Intelligence, Considering Demographic Information; A Case of Iranian EFL University Students. International journal of studies in English language and literature. 2(7), 147-157.

4) Elias, A, \& George, J. (2012). Emotional intelligence and Job Satisfaction: A Correlational Study. The international journal's research journal of commerce and behavioral sciences 1(4).

5) Joshi, R. S (2013) A Co relational Study of Emotional Intelligence and the anxiety of the Higher and Lower Economic Strata. International journal of research in all subjects in multiple languages. 1, 2-5

6) Kamran, W. \& Fatima, I (2013). Emotional intelligence anxiety and procrastination in intermediate science Students. Pakistan Journal of social and clinical psychology. 11, 3-6

7) Hashempur, S. and Mehrad, A (2014). The effect of Anxiety and Emotional Intelligence on student's learning Process. Journal of Education and social policy. 1,2,115-122

Aremu,

8) Holmes, R., Hazadiah, M. D., \&Habibah, A. (2005).A guide to research in the social sciences.Petaling Jaya: Prentice Hall.
9) Jaeger, A. J. \& Eagan, M. K. (2007).Exploring the value of emotional intelligence: $A$ means to improve academic performance. NASPA Journal, 44(3).

10) Jaeger, A. J., Bresciani, M. J., \& Ward, C. S. (2003).Predicting persistence and academic performance of first-year students. An assessment of emotional intelligence and non-cognitive variables.M.A. North Carolina State University. Retrieved January 9, 2016, from http://www.ncsu.edu/assessment/resources/news/n ov03.pdf

11) Krejcie, R. V., \& Morgan, D. W. (1970). Determining sample size for research activities. Educational and Psychological Measurement, 30, 607-610.Retrieved December 9, 2015, from http://members.multimania.co.uk/renatonunes/tab ela\%20tamanho\%20amostra.pdf

12) Kremenitzer, J. (2009, May 25). Emotional Intelligence ability and the teacher candidate. Paper presented at the annual meeting of the American Association of Colleges for Teacher EducationOnline. Retrieved April 2016, from http://www.allacademic.com/meta/p35510_index. html

13) Singh, P., Chan, Y. F. \& Sidhu, G. K. (2006). A comprehensive guide to writing a research proposal. Surrey, England: Venton Publishing. 